\title{
UPAYA MENINGKATKAN HASIL BELAJAR SISWA PADA MATA PELAJARAN MATEMATIKA DENGAN MENGGUNAKAN MODEL PEMBELAJARAN KOOPERATIF TIPE TEAMS GAMES TOURNAMENT (TGT) PADA SDN 2 SELAT DALAM KUALA KAPUAS TAHUN PELAJARAN 2016/2017
}

\author{
Oleh : Rizki Nur Anisa*Agung Riadin, M.Pd
}

\begin{abstract}
ABSTRAK
Penelitian ini bertujuan untuk (1) mengetahui peningkatan aktivitas peserta didik didik dalam kegiatan belajar mengajar dengan menggunakan model pembelajaran kooperatif tipe Teams Games Tournament (TGT) (2) mengetahui peningkatan hasil belajar matematika pada peserta didik kelas IV SDN 2 Selat Dalam Kuala Kapuas setelah menggunakan model Teams Games Tournament (TGT). Jenis penelitian yang digunakan peneliti adalah Penelitian Tindakan Kelas (PTK) yang berusaha memecahkan permasalahan yang dihadapi pada situasi sekarang. Analisis Subyek dari penelitian ini berjumlah 24 orang peserta didik, yakni 9 orang laki - laki dan 15 orang perempuan. Teknis analisis data menggunakan analisis data kualitatif dan kuantitatif. Hasil penelitian menunjukan bahwa: (1) aktivitas peserta didik dengan diterapkannya model Teams Games Tournament (TGT) menjadi lebih baik dan mengalami peningkatan di setiap siklus. Pada siklus I aktivitas peserta didik memperoleh nilai dengan rata rata 2,87 dengan kategori cukup dan meningkat pada siklus II dengan nilai rata - rata 3,75 dengan kategori baik, (2) ada peningkatan hasil belajar Matematika melalui penggunaan model Teams Games Tournament (TGT) dimana pada siklus I diperoleh nilai rata - rata 40 dengan ketuntasan klasikal 29,16\% dan meningkat pada siklus II dengan nilai rata - rata 78 dengan ketuntasan klasikal 91,6\%.
\end{abstract}

Kata Kunci : Hasil Belajar, Teams Games Tournament, Matematika

\section{PENDAHULUAN}

Pada hakikatnya pendidikan tidak akan terlepas dari manusia. Sebab urusan utama pendidikan adalah manusia. Wawasan yang dianut oleh pendidik dalam hal ini guru, akan mempengaruhi strategi atau metode yang digunakan dalam melaksanakan tugas-tugasnya. Disamping itu konsep pendidikan yang dianut akan saling berkaitan erat dengan hakikat pendidikan. Dalam pendidikan terdapat proses interaksi manusia yang sudah terencana, yang ditandai oleh keseimbangan antara subjek didik dengan kewibawaan pendidik.

Seperti yang dikutip dari Undang - Undang Sistem Pendidikan Nasional
(UUSPN) No. 20 tahun 2003 Bab I, pasal 1, menggariskan pengertian bahwa, "Pendidikan adalah usaha sadar dan terencana untuk mewujudkan suasana belajar dan proses pembelajaran agar peserta didik secara aktif mengembangkan potensi diri, kepribadian, kecerdasan, akhlak mulia, serta keterampilan yang diperlukan dirinya, masyarakat, bangsa dan negara".

Matematika merupakan salah satu ilmu yang banyak dimanfaatkan baik secara umum maupun khusus.Jika dikaitkan dengan kehidupan sehari - hari, hampir segala aspek dalam kehidupan manusia membutuhkan ilmu matematika. Secara umum, masyarakat menggunakan ilmu matematika untuk berdagang dan 
berbelanja, berkomunikasi melalui tulisan/gambar misalnya seperti membaca grafik dan presentasi, membuat catatan catatan dengan angka, membaca informasi yang disajikan dalam bentuk persen, bilangan romawi, tabel, diagram dan lain lain.

peranan penting matematika dalam kehidupan sehari - hari, banyak kalangan termasuk para siswa di sekolah yang tidak menyukai pelajaran Matematika. Matematika seringkali menjadi beban belajar bagi siswa. Betapa tidak, pembelajaran matematika yang seringkali dijejali dengan rumus dan angka cenderung membuat siswa bosan, tidak bersemangat, malas berfikir serta pasif pada saat proses pembelajaran. Pada dasarnya semua guru pasti berharap agar setiap mata pelajaran yang diajarkan dapat dimengerti, dipahami, diterima dan di kuasai oleh siswanya dengan baik. Mulyasa (2005: 164) mengatakan bahwa proses pembelajaran pada hakikatnya untuk mengembangkan aktivitas dan kreativitas peserta didik, melalui berbagai intraksi dan pengalaman belajar. Artinya, untuk menuju keberhasilan dalam mengajar, maka guru harus memiliki strategi dan keterampilan dalam menyajikan pelajaran kepada siswa.

Diluar cara guru mengajar, juga ada beberapa hal yang memicu rendahnya prestasi belajar siswa pada mata pelajaran matematika ini. Salah satunya adalah kesulitan siswa dalam memahami konsep - konsep matematika, ditambah lagi siswa enggan untuk bertanya tentang materi yang belum dipahami.Pada dasarnya semua mata pelajaran dapat bersifat menyenangkan saat kita mempelajarinya, termasuk pada mata pelajaran matematika.Akan tetapi diperlukan motivasi belajar yang tinggi, semangat belajar yang be- sar dan rasa percaya diri untuk mencapainya.Berdasarkan hal tersebut, upaya guru dalam membangun motivasi dan keaktifan belajar siswa sangatlah penting, sebab keaktifan belajar siswa menjadi penentu untuk keberhasilan pembelajaran yang dilaksanakan.

Hasil belajar merupakan tolak ukur dari keberhasilan pendidikan dan juga menjadi salah satu faktor penting dalam pelaksanaan pendidikan.Keberhasilan pendidikan dapat dilihat dari hasil belajar setelah mengikuti usaha belajar. Bila seseorang telah melakukan kegiatan belajar, maka dalam dirinya akan terjadi perubahan yang merupakan pernyataan perbuatan belajar. Hasil belajar tergantung pula dengan perencanaan pelaksanaan pembelajaran di dalam kelas.

Berdasarkan hasil observasi yang dilakukan pada hari Jum'at, 3 Februari 2017 di kelas IV SDN 2 Selat Dalam Kuala Kapuas menunjukkan hasil belajar siswa khususnya pada mata pelajaran matematika masih tergolong rendah. Dari hasil wawancara dengan Ibu Arlita Tondang, S.Pd selaku guru bidang studi matematika kelas IV SDN 2 Selat Dalam Kuala Kapuas, masih banyak siswa yang belum mencapai kriteria ketuntasan minimal.Standar untuk nilai ketuntasan yang ditentukan adalah 60.Jumlah siswa yang belum mencapai kriteria tersebut tercatat sebanyak 20 dari 24 orangsiswa.Dari data tersebut maka dapat disimpulkan bahwa masih banyak sekali peserta didik yang belum mencapai hasil belajar yang optimal.Pelaksanaan proses pembelajaran masih belum memaksimalkan keterampilan guru dalam mengembangkan metode pembelajaran sehingga mengakibatkan fokus pembelajaran hanya terpusat pada guru. Keaktifan siswa dalam proses pem- 
belajaran pun masih kurang. Tidak adanya penggunaan media dan alat peraga juga menjadi penyebab menurunnya kualitas pembelajaran serta hasil belajar matematika.

Seperti halnya yang dikemukakan oleh Toeti Soekamto dan Winataputra (Syahrudin 2015 : 3), model pembelajaransebagai kerangka konseptual yang menggambarkan prosedur yang sistematis dalam mengorganisasikan pengalaman belajar bagi para siswa untuk mencapai tujuan pembelajaran dan berfungsi sebagai pedoman bagi para perancang pembelajaran dan para pengajar dalam merencanakan dan melaksanakan aktivitas belajar mengajar. Untuk itu, setiap proses pembelajaran yang menyangkut materi, metode, media alat peraga dan sebagainya

\section{Tinjauan Pustaka}

1. Hakikat Pendidikan Matematika

a. Pengertian Matematika

Matematika diambil dari salah satu kata dalam bahasa latin yaitu "mathemata" yang memiliki arti "sesuatu yang dipelajari". Sedangkan matematika di dalam bahasa Belanda dikenal dengan sebutan "wiskunde" yang memiliki arti "ilmu pasti".Jadi secara umum dapat diartikan bahwa matematika merupakan sebuah ilmu pasti yang berkenaan dengan penalaran.Matematika merupakan salah satu ilmu yang mendasari kehidupan manusia.

Dari awal ditemukannya, matematika terus berkembang secara dinamis seiring dengan perubahan zaman.Perkembangannya tidak pernah berhenti karena matematika akan terus dibutuhkan dalam berbagai sisi kehidupan manusia.

Bidang studi Matematika merupakan salah satu komponen pendidikan dasar da- harus mengalami perubahan kearah pembaharuan. Guru akan selalu dituntut untuk lebih kreatif dan inovatif, terutama dalam menentukan model dan metode.

Berdasarkan latar belakang beserta masalah yang sudah diuraikan diatas, maka peneliti tertarik untuk mengangkat judul "Upaya Meningkatkan Hasil Belajar Siswa pada Mata Pelajaran Matematika dengan Menggunakan Model Pembelajaran Kooperatif Tipe Teams Games Tournament (TGT) pada SDN 2 Selat Dalam Kuala Kapuas Tahun Pelajaran 2016/2017". Dengan harapan model pembelajaran yang akan diterapkan ini dapat meningkatkan keaktifan serta hasil belajar peserta didik kelas IV SDN 2 Selat Dalam Kuala Kapuas.

lam bidang-bidang pengajaran dan ada pada semua jenjang pendidikan, mulai dari tingkat sekolah dasar hingga perguruan tinggi. Belajar matematika harus melalui proses yang bertahap dari konsep yang sederhana ke konsep yang lebih kompleks. Setiap konsep Matematika dapat dipahami dengan baik jika pertamatama disajikan dalam bentuk konkrit.

Definisi matematika menurut Abdurahman (2003: 252) adalah bahasa simbolis yang fungsi praktisnya untuk mengekspresikan hubungan-hubungan kuantitatif dan keruangan sehingga fungsi teoritisnya adalah untuk memudahkan berfikir. Kemudian Susanto (2013 : 184)mengatakan bahwa Matematika memiliki bahasa dan aturan yang terdefinisi dengan baik, penalaran yang jelas dan sistematis, dan struktur atau keterkaitan antara konsep yang kuat. Unsur utama pekerjaan Matematika adalah penalaran 
deduktif yang bekerja atas dasar asumsi (kebenaran konsistensi).

Dari beberapa definisi di atas, dapat disimpulkan bahwa matematika merupakan ilmu pengetahuan yang diperoleh dengan bernalar yang menggunakan

\section{b. Tujuan Pembelajaran Matematika di Sekolah Dasar}

Seseorang akan lebih mudah mempelajari matematika apabila telah didasari pada apa yang telah dipelajari orang itu sebelumnya. Karena untuk mempelajari suatu materi matematika yang baru, pengalaman belajar yang lalu dari seseorang itu akan mempengaruhi terjadinya proses belajar matematika tersebut. Dalam dokumen Standar Kompetensi mata pelajaran matematika untuk satuan SD dan MI pada kurikulum 2006 menyatakan tujuan pembelajaran matematika adalah:

1. Memahami konsep bilangan bulat dan pecahan, operasi hitung dan sifatsifatnya, serta menggunakan dalam pemecahan masalah kehidupan seharihari.

2. Memahami bangun datar dan bangun ruang sederhana, unsur-unsur dan sifatsifatnya, serta menerapkannya dalam pemecahan masalah kehidupan seharihari.

3. Memahami konsep ukuran dan pengukuran berat, panjang, luas, volume, sudut, waktu, kecepatan, debit, serta mengaplikasikan dalam pemecahan masalah sehari-hari.

4. Memahami konsep koordinat untuk menentukan letak benda dan menggunakannya dalam pemecahan masalah sehari-hari.

5. Memahami konsep pengumpulan data, penyajian data dengan tabel, gambar istilah yang didefinisikan dengan cermat, jelas, dan akurat, representasinya dengan lambang-lambang atau simbol dan memiliki arti serta dapat digunakan dalam pemecahan masalah yang berkaitan dengan

bilangan.

dan grafik (diagram), mengurutkan data, rentangan data, rata - rata hitung, modus, serta menerapkannya dalam pemecahan masalah sehari-hari.

6. Memiliki sikap menghargai matematika dan kegunaannya dalam kehidupan.

7. Memiliki kemampuan berpikir logis, kritis, dan kreatif, (Depdiknas, 2008: 235).

Secara umum, adapun tujuan mata pelajaran matematika adalah agar peserta didik memiliki kemampuan sebagai berikut :

1. Memahami konsep matematika, menjelaskan keterkaitan antar konsep dan mengaplikasikan konsep atau algortima dengan mudah, akurat, efesien, dan tepat dalam pemecahan masalah.

2. Menggunakan penalaran pada pola dan sifat, melakukan manipulasi matematika dalam membuat generalisasi, menyusun bukti, atau menjelaskan gagasan dan pernyataan matematika.

3. Memecahkan masalah yang meliputi kemampuan memahami masalah, merancang model matematika, menyelesaikan model dan menafsirikan solusi yang diperoleh.

4. Mengkomunikasikan gagasan dengan simbol, tabel, diagram, atau media lain untuk memperjelas keadaan atau masalah.

5. Memiliki sikap menghargai kegunaan matematika dalam kehidupan, yaitu memiliki rasa ingin tahu, perhatian dan minat dalam mempelajari matematika si- 
fat-sifat ulet dan percaya diri dalam pemecahan masalah.

Selain tujuan umum yang menekankan pada penataan nalar dan pembentukan sikap siswa serta memberikan tekanan pada keterampilan dalam penerapan, matematika juga memuat tujuan khusus matematika SD yaitu :

\section{c. Fungsi Pembelajaran Matematika di Sekolah Dasar}

Dengan mempelajari materi matematika diharapkan siswa akan dapat menguasai seperangkat kompetensi yang telah ditetapkan. Oleh karena itu, penguasaan materi matematika bukanlah tujuan akhir dari pembelajaran matematika, akan tetapi penguasaan materi matematika hanyalah jalan mencapai penguasaan kompetensi. Dwi Wahyuni (2013 : 27) menyatakan bahwa "Matematika berfungsi sebagai ilmu pengetahuan untuk mengambangkan kemampuan dan sikap rasional terhadap kegiatan sehari-hari dan perkembangan zaman. Matematika di SD dan MI

berfungsi untuk mengembangkan pengetahuan, nilai, sikap, dan keterampilan peserta didik dalam menghadapi gejalagejala atau kegiatan di lingkungannya."

Secara khusus, fungsi matematika adalah mengembangkan kemampuan berhitung, mengukur, menurunkan rumus dan menggunakan rumus matematika yang diperlukan dalam kehidupan sehari-hari melalui pengukuran dan geometri, aljabar, peluang dan statistika, kalkulus dan trigonometri. Metamatika juga berfungsi mengembangkan kemampuan mengkomunikasikan gagasan
1. Menumbuhkan dan mengembangkan ketrampilan berhitung sebagai latihan dalam kehidupan sehari-hari.

2. Mengembangkan kemampuan dasar matematika sebagai bekal belajar lebih lanjut.

Membentuk sikap logis, kritis, cermat, kreatif dan disiplin.

melalui model matematika, diagram, grafik, atau table

\section{Pendekatan Pembelajaran TGT \\ a. Hakikat TGT (Teams Games Tour- nament)}

Teams Games Tournament (TGT)

merupakan salah satu model pembelajaran kooperatif yang mudah diterapkan melibatkan aktivitas seluruh siswa tanpa adanya perbedaan status, melibatkan peran siswa sebagai tutor sebaya, dan mengandung unsur permainan dan reinforcement. Aktivitas siswa dengan model TGT memungkinkan siswa dapat belajar lebih rileks serta dapat menumbuhkan tanggung jawab, kerja sama, persaingan sehat dan keterlibatan belajar. Rusman (2012: 224) menjelaskan bahwa TGT adalah salah satu tipe pembelajaran kooperatif yang menempatkan siswa dalam kelompokkelompok belajar yang beranggotakan 5-6 siswa yang memiliki kemampuan, jenis kelamin, dan suku atau ras yang berbeda.Kemudian Slavin (2005:163) mengatakan bahwa TGT menggunakan turnamen akademik, dan menggunakan kuis-kuis dan sistem skor kemajuan individu, dimana peran siswa berlomba sebagai wakil tim mereka dengan anggota tim lain yang kinerja akademik sebelumnya setara seperti mereka.Berdasarkan beberapa pendapat para ahli di atas penu- 
lis memberikan kesimpulan bahwa model pembelajaran Teams Games Tournament (TGT) merupakan salah satu model pembelajaran kooperatif dimana bagiannya terdiri dari penyampaian materi secara klasikal, pengelompokan, permainan, Langkah - Langkah Penerapan TGT

Menururt Slavin (2005: 166) terdapat 5 komponen utama dalam model pembelajaran kooperatif tipe TGT, yaitu :

1. Presentasi Kelas

Pada tahap ini materi pembelajaran langsung seperti yang sering dilakukan atau diskusi pelajaran yang dipimpin oleh guru. Selama presentasi kelas, siswa harus benar-benar memperhatikan ketika guru menejelaskan materi, karena hal ini akan membantu siswa untuk dapat mengerjakan lembar kerja kelompok pada saat bekerja kelompok.

2. Kegiatan Kelompok (Teams)

Tim terdiri dari empat atau lima siswa yang dipilih secara heterogen dalam kemampuan akademik dan jenis kelamin. Setiap kelompok dipilih satu orang sebagai ketua kelompok. Fungsi utama dari ketua tim adalah memastikan bahwa semua anggota tim benar-benar belajar, dan lebih khususnya lagi adalah untuk

\section{MODEL PENELITIAN}

Jenis penelitian yang digunakan pada penelitian ini adalah penelitian tindakan kelas (PTK) yang bertujuan untuk memperbaiki dan meningkatkan kondisikondisi belajar serta kualitas pembelajaran.Wina Sanjaya (Harjoko 2014:27) menyatakan "Penelitian Tindakan.elas Adapun rancangan penelitian yang digunakan dalam penelitian ini yaitu dengan menggunakan model Stephen Kemmis dan Robin M.C Taggart. Prosedur yang digunakan oleh model Kemmis dan M.C Taggart yang terdiri turnamen, dan penghargaan kelompok. Model Team Games Tournament (TGT)akan dapatmenambah motivasi, rasa percaya diri, toleransi, kerjasama dan pemahaman materisiswa.

mempersiapkan anggotanya untuk mengerjakan LKS dengan baik. Pada tahap ini siswa berdiskusi memecahkan masalah (soal) yang harus diselesaikan serta harus saling membantu dalam memahami materi yang sedang dibahas. Karena tahap ini merupakan tahapan dimana siswa mempersiapkan diri dan kelompoknya menuju meja turnamen

3. Permainan (Games)

Games terdiri dari pertanyaan-pertanyaan yang dirancang untuk menguji pengetahuan yang didapat siswa dari penyajian kelas dan pelaksanaan kerja tim. Game tersebut dimainkan di atas meja dengan tiga orang siswa, yang mewakili masingmasing tim yang berbeda. timnya masingmasing, tambahkan seluruh skor anggota tim, dan bagilah dengan jumlah anggota tim yang bersangkutan. Diberikan tiga tingkatan penghargaan yang didasarkan pada skor rata-ratatim

(PTK) dapat diartikan sebagai proses pengkajian masalah pembelajaran di dalam kelas melalui refleksi diri dalam upaya untuk memecahkan masalah tersebut dengan cara melakukan berbagai tindakan yang terencana dalam situasi nyata serta menganalisis setiap pengaruh dari perlakuan tersebut".

atas 4 fase kegiatan meliputi: perencanaan (plan), pelaksanaan tindakan (action), observasi (observation) dan refleksi (reflection). Desain keempat tahap atau fase tersebut digambarkan sebagai berikut 


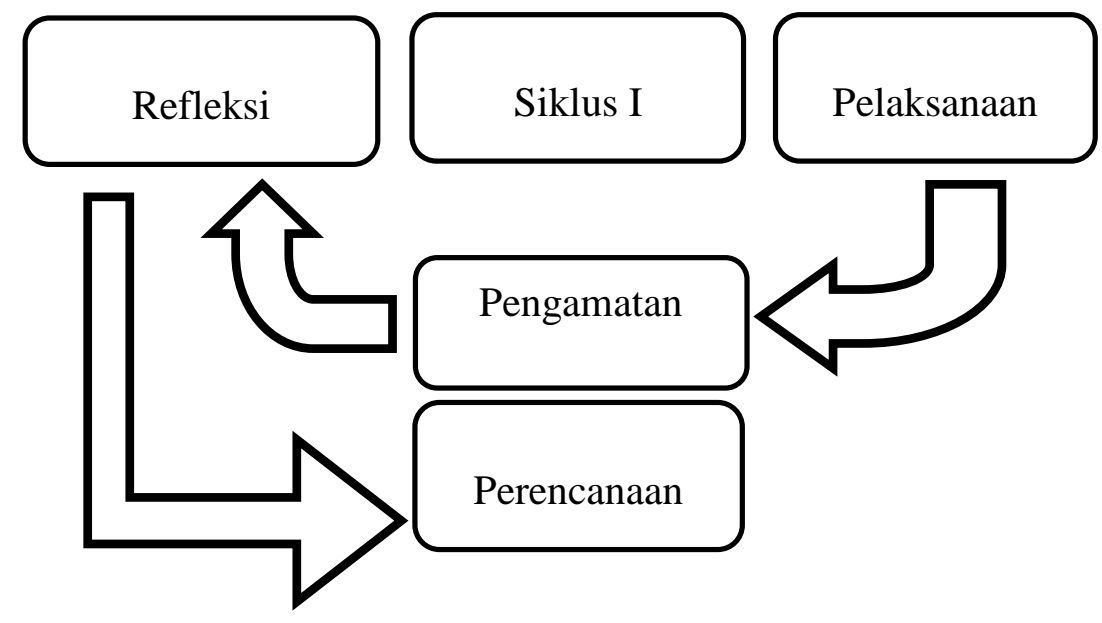

\section{HASIL DAN PEMBAHASAN}

Pembahasan hasil penelitian di kelas IV SDN 2 Selat Dalam Kuala Kapuas menggunakan Model Pembelajaran Kooperatif tipe TGT (Teams Games Tournament) pada mata pelajaran Matematika adalah sebagai berikut:Berdasarkan analisis data yang dilakukan terhadap aktivitas peserta didik maka dapat diperoleh hasil aktivitaspeser-

1. Hasil Belajar Peserta Didik kelas IV SDN 2 Selat Dalam Kuala Kapuas menggunakan Model Pembelajaran Kooperatif tipe TGT (Teams Games Tournament)

Berdasarkan analisis data yang dilakukan terhadap hasil belajar peserta didik, maka dapat diperoleh hasil belajar peserta didik dari tes awal, tes akhir siklus I dan tes akhir siklus II. Pada tes awal, siklus II hasil belajar peserta didik meningkat dengan perolehan nilai rata rata 78 dan ketuntasan klasikal 91,6\% dengan kriteria sangat tercapai.

Hasil penelitian ini sejalan dengan hasil penelitian terdahulu yaitu hasil penelitian dari Komang Sudamayanto, I Wayan Darsana, I Ketut Adnyana Putra (2014 : 9) menunjukkan adanya peningkatan pada hasil belajar IPA dimana ke- ta didik pada setiap siklusnya. Pada siklus I, aktivitas peserta didik memperoleh skor rata - rata 2,87 dengan kriteria cukup baik. Pada siklus II, aktivitas peserta didik memperoleh skor rata - rata 3,75 dengan kriteria baik. Hal ini menunjukan bahwa aktivitas peserta didik menjadi baik dan meningkat dengan diterapkannya model pembelajaran kooperatif tipe TGT.

hasil belajar peserta didik memperoleh nilai rata - rata 28 (dibawah standar KKM 60) dengan ketuntasan klasikal 8,3\% dengan kriteria yang sangat belum tercapai. Pada siklus I hasil belajar peserta didik memperoleh nilai rata - rata 40 dengan ketuntasan klasikal 29,16\% dengan kriteria yang juga masih belum tercapai.

Pada

tuntasan klasikal pada siklus I mencapai $40 \%$ kemudian meningkat menjadi $100 \%$ pada siklus II. Dengan demikian, dapat disimpulkan bahwa model pembelajaran kooperatif tipe Teams Games Tournament (TGT)dapat meningkatkan hasil belajar peserta didik.

\section{KESIPULAN}

Berdasarkan data hasil penelitian yang telah dibahas, maka dapat disimpulkan : 
Aktivitas belajar Matematika dengan menggunakan model pembelajaran kooperatif tipe Teams Games Tournament (TGT) pada peserta didik kelas IV SDN 2 Selat Dalam Kuala Kapuas menjadi baik. Hal tersebut terlihat dari keaktifan dan semangat peserta didik dalam mengikuti pembelajaran dan hasil obGames Tournament (TGT) pada peserta didik kelas IV SDN 2 Selat Dalam Kuala Kapuas.Peningkatan tersebut dapat dilihat dari hasil belajar peserta didik pada mata pelajaran Matematika khususnya pada materi Lambang Bilangan Romawi. Pada siklus I perolehan nilai rata-rata peserta didik 40 dengan ketuntasan klasikal $29,16 \%$ dan mengalami peningkatan padasiklus II dengan rata-rata nilai 78 dan ketuntasan

\section{DAFTAR PUSTAKA}

Abdurrahman, Mulyono (2003). Pendidikan Bagi Anak Berkesulitan Belajar. Jakarta: Rineka Cipta

Slavin, R. (2005). Cooperative Learning : Theory, Research and prac- servasi peserta didik menyatakan adanya peningkatan, dimana pada siklus I di peroleh rata - rata 2,87 dengan kategori cukup kemudian pada siklus II meningkat menjadi 3,75 dengan kategori baik.Adanya peningkatan hasilbelajar Matematika dengan diterapkannya model pembelajaran kooperatif tipe Teams tice(3nd.Ed.) Terjemahan oleh Lita. 2009. Bandung : Nusa Media.

Suarjana . (2000). Model Pembelajaran Teams Games Tournament. Vol 3 No.1.Jurnal Pendidikan Teknologi Informasi Dan Komunikasi (PTIK).hal 10.

Rusman, (2012). Model-model Pembelajaran: Mengembangkan Profesionalisme Guru, RajaGrafindo Persada, Jakarta

Harjoko (2014). Meningkatkan Hasil Belajar Matematika Melalui Penerapan Model Pembelajaran Kooperatif Tipe TGT (Teams Games Tournament) Pada Siswa Kelas V SDN Kedungjambal 02 Kab.Sukoharjo Tahun Ajaran 2013/2014. Yogyakarta : Universitas Negeri Yogyakarta. 
Tunas Jurnal Pendidikan Guru Sekolah Dasar,Desember 2017, Volume 3 Nomor 1, (53-61) ISSN 2477-6076 